\title{
HUBUNGAN ANTARA DURASI TIDUR DAN KUALITAS HIDUP DENGAN KEGEMUKAN PADA MAHASISWA KEPERAWATAN UMP
}

\author{
Cindy yuni fitri ${ }^{1}$,Supriyadi ${ }^{2}$ \\ ${ }^{1}$ Fakultas ilmu kesehatan, universitas muhammadiyah purwokerto \\ Email:cinndyyunifitri24@gmail.com \\ ${ }^{2}$ Dosen fakultas ilmu kesehatan, universitas muhammadiyah purwokerto \\ Email:prisandi31@gmail.com
}

\begin{abstract}
Background: Overweight and obesity have now become a health problem that is common and continues to increase at present. Overweight and Obesity can affect all ages ranging from children, adolescents, to the elderly, and all genders, both male and female. Factors that influence obesity include genetics, physical activity, and diet. Objectives: To determine the relationship between sleep duration and quality of life with obesity among nursing students at Muhammadiyah University of Purwokerto. Methods: The research method used was observational analytical approach. cross sectional. The sampling technique was random sampling with a sample size of 30 respondents who matched the inclusion and exclusion criteria. Data analysis used univariate and bivariate chi square tests. Results: (1) There was a relationship between sleep duration and obesity in students with a value of $=0.025$. 2) There is no relationship between the quality of life and obesity in students with a value of $=0.855$. Conclusion: The lack of sleep duration can affect the occurrence of obesity in a person and there is no effect on the quality of life with obesity.
\end{abstract}

Keywords: sleep duration, quality of life, obesity, college students.ABSTRAK

Latar Belakang:Kegemukan dan obesitas saat ini sudah menjadi suatu masalah kesehatan yang banyak terjadi dan terus meningkat pada masa kini. Kegemukan dan Obesitas dapat mengenai semua usia mulai dari anak-anak, remaja, hingga orang tua,dan semua jenis kelamin baik laki-laki maupun perempuan. Faktor-faktor yang mempengaruhi kegemukan antara lain yaitu genetik, aktivitas fisik, dan pola makan.Tujuan:Untuk mengetahui Hubungan antara durasi tidur dan kualitas hidup dengan kegemukan pada mahasiswa keperawatan sl universitas muhammadiyah purwokerto.Metode: Metode penelitian yang digunakan adalah analitik observasional dengan pendekatan cross sectional. Teknik pengambilan sampel dengan cara Random Sampling dengan jumlah sampel 30 responden yang sesuai kriteria inklusi dan eksklusi.Analisa data menggunakan univariat dan bivariat dengan uji chi square.Hasil: (1) Ada hubungan antara durasi tidur dengan kegemukan pada mahasiswa dengan nilai =0,025.(2)Tidak terdapat hubungan antara kualitas hidup dengan kegemukan pada mahasiswa dengan nilai =0,855.Kesimpulan:Durasi tidur malam yang kurang dapat mempengaruhi terjadinya kegemukan terhadap seseorang dan tidak ada pengaruh pada kualitas hidup dengan kegemukan.

Kata Kunci: durasi tidur, kualitas hidup, kegemukan, mahasiswa.

\section{PENDAHULUAN}

Kegemukan dan obesitas saat ini sudah menjadi suatu masalah kesehatan yang banyak terjadi dan terus meningkat pada masa kini.Kegemukan dan Obesitas dapat mengenai semua usia mulai dari anak-anak, remaja, hingga orang tua, dan semua jenis kelamin baik lakilaki maupun perempuan (Sumanto,2009). Kegemukan dan obesitas adalah dua istilah yang berbeda. Kegemukan adalah kondisi berat badan seseorang melebihi berat badan normal pada umumnya. Kegemukan disebabkan oleh kombinasi antara asupan energi makanan yang berlebihan, kurangnya 
aktivitas dan kerentangan genetik. Kegemukan dinilai berdasarkan Indeks Massa Tubuh (IMT), dan selanjutnya berdasarkan distribusi lemak melalui rasio pinggang, dan perut. Seseorang kegemukan jika IMT (Indeks MassaTubuh) berada pada rentang $>27,5 \mathrm{Kg}$ (Frank,2012). Obesitas adalah suatu keadaan dimana terjadi penumpukan lemak tubuh yang berlebih sehingga berat badan seseorang jauh di atas normal (Ekky dan Rahardja, 2014).World Health Organization (WHO) 2013 Melaporkan pravalensi overweight dan obesitas meningkat dua kalinya antara tahun 1980 dan 2008, 10\% laki-laki dan $14 \%$ perempuan mengalami obesitas. sedangkan di tahun 1980 angka itu masih berada di $5 \%$ dan 8\% untuk laki-laki dan perempuan. Di Asia masalah obesitas meningkat tajam dalam kurun waktu beberapa puluh tahun terakhir. Di China, prevalensi obesitas dan overweight (BMI $\geq 25 \mathrm{Kg} / \mathrm{m} 2$ ) meningkat $400 \%$. Pravalensi obesitas terbesar berada di negara-negara maju seperti negara Amerika Serikat menepati urutan teratas. Di Indonesia prevalensi kegemukan pada penduduk diatas usia 18 tahun 2010 menunjukkan angka cukup tinggi terdapat $21,7 \%$ penduduk diatas usia 18 tahun yang termasuk golongan kegemukan dan obesitas. Prevalensi kegemukan dan obesitas lebih banyak diderita oleh Laki-laki memiliki prevalensi $25,5 \%$ sedangkan perempuan memiliki prevalensi $16,9 \%$, prevalensi kurus sebesar $12,6 \%$ dan prevalensi normal sebesar65,8\%(Depkes,2010).

Angka kejadian kegemukanterus meningkat di kalangan remaja khususnya pada mahasiswa. Dimana kualitas hidup seseorang berkaitan dengan gaya hidup dimana gaya hidup tidak sehat dapat menyebabkan kualitas hidupnya tidak baik seperti kurangnya melakukan olahraga dan mengkonsumsi makan-makanan cepat saji atau berlemak tinggi sehingga mengakibatkan terjadi kelebihan berat badan. Durasi tidur yang tidak teratur dengan kebutuhan tubuh seperti tidur $<7$ jam/hari. Bertujuan untuk mengetahui Hubungan Antara Durasi Tidur Dan Kualitas hidup Dengan Kegemukan Pada Mahasiswa Keperawatan UMP.

\section{METODE PENELITIAN}

Penelitian ini menggunakan metode Kuantitatif dengan pendekatan Cross Sectional. Teknik Pengambilan sampel dalam penelitian ini menggunakan random sampling yaitu merupakan pengambilan sampel secara acak berjumlah 30 responden. Alat yang digunakan dalam penelitian ini adalah kuesioner dan pengukuran TB dan BB. Analisa data menggunakan uji Chi Square. Variabel yang diukur adalah durasi tidur, kualitas hidup dan kegemukan. Penelitian ini dilakukan bulan Desember 2019 di fakultas ilmu kesehatan UMP.

\section{HASIL DAN PEMBAHASAN}

Analisis Univariat

Karakteristik Responden

Tabel 1 Distribusi frekuensi reponden berdasarkan Umur.

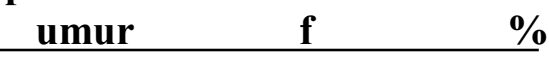




\begin{tabular}{ccc}
18 & 4 & 13,3 \\
19 & 10 & 33,3 \\
20 & 8 & 26,7 \\
21 & 8 & 26,7 \\
\hline
\end{tabular}

Berdasarkan Tabel 1 diketahui bahwa karakteristik responden sebagian besar berumur 19 tahun sebanyak 10 orang $(33,3 \%)$

Tabel 2 Distribusi frekuensi karakteristik reponden berdasar kan jenis kelamin

\begin{tabular}{lll} 
Jenis & F & \% \\
\hline \hline Kelamin & & \\
Laki-laki & 17 & 56,7 \\
Perempuan & 13 & 43,3
\end{tabular}

Berdasarkan Tabel 2 diketahui bahwa responden berjenis laki-laki sebanyak 17 orang $(56,7 \%)$.

Penelitian ini didukung oleh penelitian yang dilakukan Damayanti (2018) jumlah responden yang berumur 18 tahun, yaitu sebanyak 13 orang $(32,5 \%)$ dari jumlah responden sebanyak 40 remaja. Dimana semakin bertambahnya usia maka semakin berisiko mengalami obesitas karena terjadinya peningkatan akumulasi lemak didalam tubuh yang didukung oleh perubahan pola makan yang tidak seimbang yaitu tinggi karbohidrat, tinggi lemak dan rendah serat dengan kata lain kejadian kegemukan cenderung meningkat pada usia dewasa. Menurut Angles (2013) bahwa umur dan jenis kelamin merupakan faktor yang tidak dapat diubah pada banyak faktor risiko seperti pada kejadian overweight. Dimana ketidakseimbangan antara asupan dankeluaran energi mengakibatkan kelebihan berat badan. Obesitas yang muncul pada usia remaja cenderung berlanjut pada usia dewasa dan lansia.

Tabel 3 Distribusi frekuensi reponden berdasarkan tingkat semester

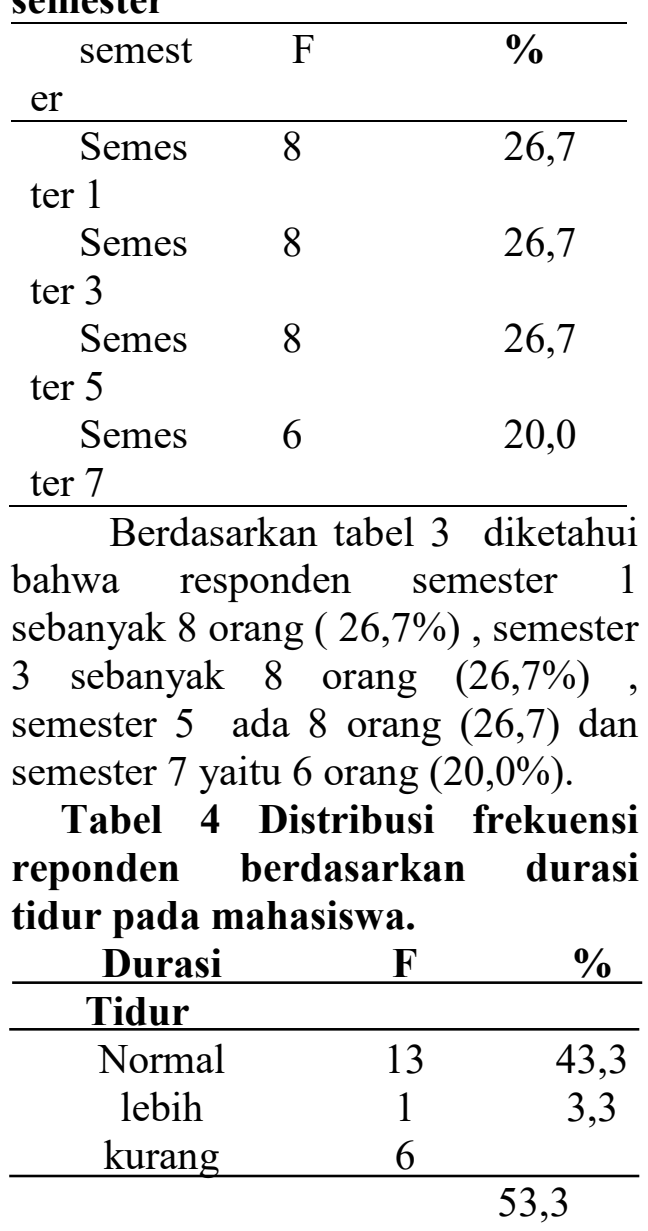

Berdasarkan Tabel 4 diketahui bahwa responden mempunyai durasi tidur kurang sebanyak 6 orang $(53,3 \%)$.Penelitian ini sejalan dengan penelitian yang dilakukan oleh Damayanti (2018) menunjukkan bahwa terdapat durasi tidur remaja kurang dari 7 jam sebesar ( 95\%), sedangkan durasi tidur cukup 7-8 jam sebesar (92,5\%). Dimana responden dengan durasi tidur 
kurang cenderung mengalami overweight atau obesitas.

Durasi tidur memiliki peran terhadap pengaturan metabolisme hormon leptin dan ghrelin, sehingga durasi tidur yang singkat dimalam hari berpengaruh pada ketidakseimbangan hormon. Durasi tidur yang kurang dapat meningkatkan nafsu makan karena terjadi peningkatan hormon gherlin dimana hormon ini berfungsi untuk meningkatkan nafsu makan seseorang dan menurunkan hormon leptin dimana hormon ini yang berfungsi untuk mengendalikan nafsu makan seseorang.

Tabel 5 Distribusi frekuensi responden berdasarkan kualitas hidup pada mahasiswa.

\begin{tabular}{lll}
\hline $\begin{array}{c}\text { Kualitas } \\
\text { hidup }\end{array}$ & F & $\%$ \\
\hline
\end{tabular}

\begin{tabular}{ccc} 
Baik & 6 & 20,0 \\
$\begin{array}{c}\text { Sangat } \\
\text { baik }\end{array}$ & 24 & 80,0 \\
\hline
\end{tabular}

Berdasarkan Tabel 5 diketahui bahwa responden dengan kategori kualitas hidup sangat baik sebanyak 24 orang $(80,0 \%)$ dan kualitas hidup baik 6 orang $(20,0 \%)$. Berdasarkan penelitian yang dilakukanoleh AlAkour et,all (2011) menyatakan bahwa remaja yang memiliki kualitas hidup rendah dapat berdampak pada kelebihan berat badan. Terdapat hubungan kelebihan berat badan bagi remaja yang memiliki kualitas hidup rendah, remaja yang memiliki kualitas hidup baik memiliki dampak yang kecil tehdapat kejadian obesitas, akan tetapi remaja yang memiliki kualitas hidup buruk memiliki kemumngkinan dampak kelebihan berat badan yang sangat tinggi.

Tabel 6 distribusi responden berdasarkan kegemukan pada mahasiswa.

\begin{tabular}{|c|c|c|}
\hline Kegemukan & $\mathbf{F}$ & $\%$ \\
\hline Kekurangan & 1 & 3 , \\
\hline $\begin{array}{l}\text { berat badan } \\
\text { tingkat ringan }\end{array}$ & & 3 \\
\hline Kekurangan & 2 & 6 \\
\hline $\begin{array}{l}\text { berat badan } \\
\text { tingkat berat }\end{array}$ & & 7 \\
\hline Normal & 19 & $3,3^{6}$ \\
\hline Kelebihan & 1 & 3, \\
\hline $\begin{array}{l}\text { berat badan } \\
\text { tingkat ringan }\end{array}$ & & 3 \\
\hline Kelebihan & 7 & 2 \\
\hline $\begin{array}{l}\text { berat badan } \\
\text { tingkat berat }\end{array}$ & & 3,3 \\
\hline
\end{tabular}

Berdasarkan tabel 6 bahwa responden yang memiliki berat badan normal sebanyak 19 orang $(63,3 \%)$, kelebihan berat badan tingkat berat 7 orang $(23,3 \%)$,kelebihan berat badan tingkat ringann 1 orang $(3,3 \%)$ kekurangan tingkat berat 2 orang $(6,7 \%)$ dan kekurang tingkat ringa orang $(3,3 \%)$.Hasil penelitian ini menunjukkan bahwa sebagian besar responden berat badannya dalam kategori normal. Menurut Adityawarma (2010) menyatakan bahwa overweight ditentukan dengan nilai IMT antara $25-29,99 \mathrm{~kg} / \mathrm{m} 2$. World Health Organization (WHO) memprediksi bahwa penyakit tidak menular (PTM) berkontribusi sebesar $56 \%$ dari semua kematian dan $44 \%$ dari beban penyakit pada negaranegara yang ada di Asia Tenggara. 
Di indonesia penyakit kardiovaskuler merupakan penyebab utama kematian. Obesitas terjadi karena adanya kelebihan energi yang disimpan dalam bentuk jaringan lemak. Gangguan keseimbangan energi ini dapat disebabkan oleh faktor eksogen (obesitas primer) sebagai akibat nutrisional dan faktor endogen (obesitas sekunder) akibat adanya kelainan hormonal, sindrom atau efek genetik. Pengaturan keseimbangan energi diperankan

Analisis Bivariat

Tabel 7 hubungan antara durasi tidur dan kualitas hidup dengan kegemukan pada mahasiswa keperawatan S1 UMP

Kegemukan

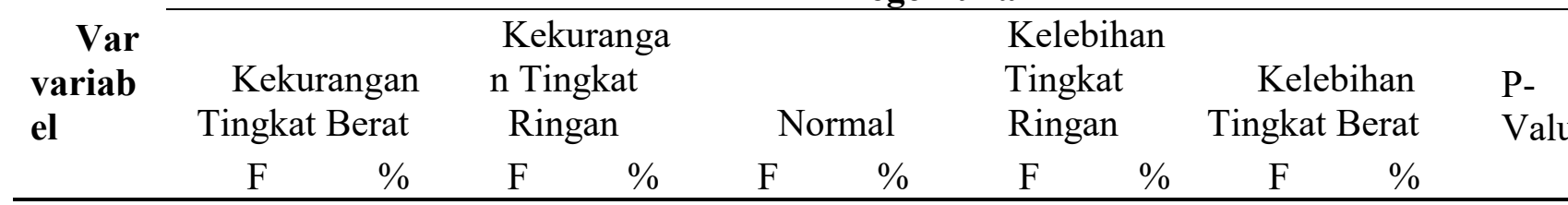

\section{Durasi Tidur}

\begin{tabular}{|c|c|c|c|c|c|c|c|c|c|c|}
\hline $\begin{array}{l}\text { Nor } \\
\text { mal }\end{array}$ & 1 & 7,7 & 0 & 0 & 8 & 61,5 & 1 & 7.7 & 3 & $\begin{array}{r}2 \\
3,1\end{array}$ \\
\hline${ }_{\mathrm{h}}$ Lebi & 0 & 0 & 1 & $\begin{array}{l}10 \\
0\end{array}$ & 0 & 0 & 0 & 0 & 0 & 0 \\
\hline $\begin{array}{l}\text { Kur } \\
\text { ang }\end{array}$ & 0 & 0 & 1 & 6,2 & 1 & 68,8 & 0 & 0 & & $\begin{array}{c}2 \\
5,0\end{array}$ \\
\hline
\end{tabular}

Kualitas Hidup

\begin{tabular}{|c|c|c|c|c|c|c|c|c|c|c|}
\hline $\begin{array}{l}\text { Baik } \\
\text { San }\end{array}$ & 0 & 0 & 0 & 0 & 4 & $\begin{array}{l}66 \\
7\end{array}$ & 0 & 0 & 2 & $\begin{array}{r}3 \\
3,3\end{array}$ \\
\hline $\begin{array}{l}\text { gat } \\
\text { baik }\end{array}$ & 1 & 4,2 & 2 & 8,3 & $5^{1}$ & $\begin{array}{l}62, \\
5\end{array}$ & 1 & 4,2 & 5 & $\begin{array}{r}2 \\
0,8\end{array}$ \\
\hline lah & 1 & 3,3 & 2 & 6,7 & $9^{1}$ & $\begin{array}{l}63, \\
3\end{array}$ & 1 & 3,3 & 7 & $3,3^{2}$ \\
\hline
\end{tabular}


Berdasarkan Tabel 7 Berdasarkan hasil penelitian yang ditunjukkan pada tabel $4.7 \mathrm{di}$ atas disimpulkan bahwa dari total 30 mahasiswa didapatkan hasil bahwa sebagian besar mahasiswa yang mempunyai durasi tidur kurang yaitu sebanyak $11 \quad(68,8 \%)$ dengan kondisi berat badan kategori normal. Hasil statistik dengan uji Chi Square antara durasi tidur dengan kegemukan didapatkan $p$ value $=0,025<\alpha=0,05$ artinya $\mathrm{H} 0$ ditolak dan H1 diterima hal tersebut menunjukkan bahwa ada hubungan yang bermakna antara variabel durasi tidur dengan variabel kegemukan $(\mathrm{p}<$ $0,05)$.

Hasil uji statistik antara kualitas hidup dengan kegemukan didapatkan hasil bahwa sebagian besar mahasiswa yang memiliki kualitas hidup sangat baik yaitu sebanyak 15 orang $(62,5 \%)$ dengan kondisi berat badan normal dan kualitas hidup baik 4 orang $(66,7 \%)$ dengan kondisi berat badan normal. Uji statistik Chi Square antara kualitas hidup dengan kegemukan pada remaja didapatkan hasil nilai $p$-value $=0,855>\alpha=$ 0,05 yang berarti tidak terdapat hubungan antara kualitas hidup dengan kegemukan pada remaja $(p>0,05)$. Penelitian ini juga sejalan dengan penelitian Garaulet (2011) yang dilakukan pada remaja di Eropa bahwa terdapat hubungan antara durasi tidur pendek dengan obesitas. Penurunan jumlah jam tidur dikaitkan dengan peningkatan nilai indeks massa tubuh dikarenakan penurunan kadar leptin dan peningkatan kadar ghrelin, yang dapat mempengaruhi rasa lapar dan nafsu makan, meningkatkan resiko makan berlebih sehingga dapat mengakibatkan obesitas. Selain dapat menyebabkan obesitas, orang yang memiliki jumlah tidur kurang 5 jam selama 8 hari menunjukkan penurunan sensitivitas insulin secara konsisten tanpa adanya kompensasi dari responsivitas sel b pankreas dan pada akhirnya akan meningkatkan resiko timbulnya diabetes.

Berdasarkan penelitian yang dilakukan oleh Al-Akour et,all (2011) menyatakan bahwa remaja yang memiliki kualitas hidup rendah dapat berdampak pada kelebihan berat badan. Terdapat hubungan kelebihan berat badan bagi remaja yang memiliki kualitas hidup rendah, remaja yang memiliki kualitas hidup baik memiliki dampak yang kecil tehadapat kejadian obesitas, akan tetapi remaja yang memiliki kualitas hidup buruk memiliki kemungkinan dampak kelebihan berat badan yang sangat tinggi.

\section{SIMPULAN}

Hasil pe Hasil penelitian ini 
menunjukkan Durasi tidur responden sebagian besar memiliki durasi tidur kurang, dan kualitas hidup responden sebagian besar dalam kategori kualitas hidup sangat baik. Terdapat hubungan antara durasi tidur dengan kegemukan pada mahasiswa keperawatan UMP.Tidak terdapat hubungan antara kualitas hidup dengan kegemukan pada mahasiswa keperawatan UMP.

\section{DAFTAR PUSTAKA}

Adamkova V, Hubacek J.A,.Lanska V, Kravola Lesna I, Eleminsky M , 2009. Association between duration of the sleep and body weight.Physiological research 58.

Akour, Khader, Khassawneh, Bawadi, 2011. Health related quality of life of adolescents with overweight or obesity in the north of jordan.blackwell publishing ltd,child: care, health and development ,38, 2 ,237- 243.

Alfiyanti, 2009. Insomnia gangguan sulit tidur. Yogjakarta : Kanisius

Ali M , 2011. Psikologi Remajadan Perkembangan Peserta Didik.Jakarta: Bumi Aksara.

Anbarasan,2015.Gambaran kualitas hidup lansia penderita hipertensi di wilayah kerja puskesmas rendang. pada periode 27 febuari-14 maret, 2089-9684 vol.2 no 1. Diambil pada tanggal 25 November 2019. Dari : http:// ejournal.uu.ac.id.

Angels, Marunduh, Rampengan, 2013.Gambaran durasi tidur pada remaja dengan kelebihan berar badan. Jurnal eBiomedik (eBM), Volume 1, Nomor 2. Diambil 20 november 2019 dari http:// ejournal.us.ac.id.

Aqilah S, 2010. Obesitas dan terapi praktis. Jakarta : Kanasius

Benedict C, Lassen A, Schultes B, Schioth H, 2011. Acute sleep deprivation reduces energy expenditure in health men. A mj Clin Nutr 93: 1229-1236.

BillingtonD,2010.TheNew Zealand World Health Organization Quality Of Life. (WHOQOL) Group. Journal Of The New Zealand Medical Association. Vol. 123.

Cantika A 2012 .The relationship between quality of life with obesity in adolescent.Public Health Journal.40 (2).96-101.

Cappucino S , Syander, 2011. Meta analysis of short sleep duration and obesity. Of models and meansure washington.

Champan V, 2012. Tingkat asupan energi dan durasi tidur dengan indeks massa tubuh. Jurnal kesehatan 01 (01):145-155. Diambil 15 november 2019.Dari http:// ejournal.ums.ac.id

Chaput J.P , Brunet M , Tremblog A , 2006. Relationship between short sleeping hours and chilhood overweight dan obesity result from thequebecen forme project. International journal of obesity.

Dahlan, 2010. Metode penelitian keperawatan dan teknik analisis data. Jakarta : Salemba Medika.

Damayanti,Sumarni ,Mundiastuti, 2018. Hubungan durasi tidur dengan kejadian overweight dan obesitas pada remaja di lingkungan kampus cDOI: 10.2473/amnt.v3i2.89-93.diambil 15 november 2019.Dari : http :// ejournal.unair.ac.id.

Dariyo A, 2008. Mencegah dan mengatasi kegemukan. Jakarta : Swadaya.

Depkes RI , 2014. Klasifikasi indeks massa tubuh (IMT). Jakarta: Depkes.

Depkes RI, 2010. Riset Kesehatan Dasar. Jakarta: Badan Penelitian dan pengembangan Kesehatan Kementrian Kesehatan RI.

Dorland S, 2009. Obesitas dan sindroma metabolik. Jakarta : EGC.

Fitriana \& Ambarani. 2012. Prinsip dasar dan Aplikasi Penulisan Laporan Pendahuluan dan Strategi Pelaksanaan Tindakan Kep. Jakarta:EGC. 